\title{
Analysis of Burnout Levels of Judo Coaches in the COVID-19 Period: Mixed Method
}

\author{
Özgür Aktaş (Corresponding author)
}

School of Physical Education and Sport, Department of Physical Education and Sport Kilis 7 Aralık University, Mehmet Sanlı Mah. Doğan Güreş Paşa Bul. No:134 Kilis, Turkey

Tel: 90-348-814-2666 E-mail: ozguraktas@kilis.edu.tr

\section{Berna Karakoç}

School of Physical Education and Sport, Department of Physical Education and Sport Kilis 7 Aralık University, Mehmet Sanlı Mah. Doğan Güreş Paşa Bul. No:134 Kilis, Turkey Tel: 90-348-814-2666_E-mail: bernakarakoc@kilis.edu.tr

\section{Önder Karakoç}

School of Physical Education and Sport, Department of Physical Education and Sport Kilis 7 Aralık University, Mehmet Sanlı Mah. Doğan Güreş Paşa Bul. No:134 Kilis, Turkey Tel: 90-348-814-2666_E-mail: onderkarakoc@kilis.edu.tr

Received: April 19, $2021 \quad$ Accepted: May 21, $2021 \quad$ Published: May 31, 2021

doi:10.5296/jei.v7i1.18549 URL: https://doi.org/10.5296/jei.v7i1.18549

\begin{abstract}
This study was carried out to find out the burnout levels of judo coaches in COVID-19 period and to show how they will approach their profession and athletes in the period after the pandemic. 136 judo coaches from different coaching levels participated in the study. Maslach Burnout Inventory was used in the study. In addition, 3 qualitative questions were prepared by the researchers to find out the emotions of coaches during and after the pandemic and how they approached their athletes. IBM SPSS 22 statistical program was used to analyze the data in the study. Since the data were not normally distributed, non-parametric Mann Whitney U was used in paired group comparisons, while Kruskal Wallis $\mathrm{H}$ test was used for the comparison of more than two groups and significance level was taken as $p<.05$. Content
\end{abstract}


analysis method was used to analyze the 3 qualitative questions. As a result, burnout levels of the judo coaches in the study were found to be low. No significant difference was found between the variables of gender, age and coaching level and burnout level. In addition, while coaches stated that they missed their profession and were waiting excitedly for trainings to start, more than half of them stated that their approaches to athletes will change after the pandemic.

Keywords: Burnout, Coach, COVID-19, Judo, Pandemic, Stress, Mental toughness

\section{Introduction}

Novel severe acute respiratory syndrome coronavirus 2 (SARS-CoV-2), which emerged in the last months of 2019, affected the countries in Asia, Ocenia, North, Middle and South America as well as most European countries due to the increase in the rate of spread in the first months of 2020 (WHO, 2020). It has been reported that the transfer of COVID-19 will be quite easy in sports environments, especially in contact sports, due to its long incubation period, being viable, showing milder symptoms and transmission characteristics (Wong et al., 2020). Due to these characteristics of the virus, the postponement or cancellation of the events planned to be carried out in the national and international arena has become a current issue because protecting athletes' health and taking precautions to prevent them from being injured or getting sick is one of the main goals of sport. The measures to be taken for these purposes are important in terms of protecting athletes and preventing the virus from spreading (Aygün \& Ünal, 2020). In addition to mass participation events such as marathon races, economically profitable football leagues were also either postponed or cancelled (Yeo, 2020). Even the Summer Olympic Games, which were not postponed due to any medical reasons in history and which were planned to be held in Japan in 2020 and considered as the world's largest sport organization, have been postponed until June 2021 (Dhillon, 2020).

It has been found that during the COVID-19 quarantine, communication ways of individuals (including coaches and athletes) have changed significantly (Dalton et al., 2020; Yu et al., 2020) and there has been an increase in the level of stress perceived by coaches (Santi et al., 2021). In addition to a study which found that the communication between coach and athlete was effective on burnout states (Isoard-Gautheur et al., 2016), in another study which was conducted by Monfared et al. (2021) it was found that the level of saliva cortisol, which is a physiological indicator of stress, was also effective on the burnout states perceived by athletes. Considering these studies, the burnout levels of coaches, who are stakeholders of sport, during the pandemic period have been a matter of curiosity.

Maslach and Jackson (1981) grouped the perceived burnout state in three dimensions as emotional exhaustion, depersonalization and personal accomplishment. Emotional exhaustion is defined as the emotional fatigue that occurs as a result of the negative situations individuals have experienced in their current jobs. Depersonalization is a situation in which individuals have decreased interest in their current job or the individuals they communicate with. Personal accomplishment is individuals' feeling unsuccessful in their current job. In addition, it was found that burnout has significant effects on team performance and coaches' health and well-being (Goodger, Lavallee, Gorley, \& Harwood, 2007). 
During the pandemic period, in addition to studies on physical characteristics of athletes (Baggish et al., 2020; Hull, Loosemore, \& Schwellnuss, 2020; Yousfi et al., 2020; Wilson et al., 2020; Raipal et al., 2021), studies have also been conducted which examine the psychological and sociological states of both coaches and athletes and provide recommendations for the pandemic period and post-pandemic period (Schinke et al., 2020; Håkansson, Jönsson, \& Kenttä, 2020; Öktem, Şipal, Kul, \& Dilek, 2020; Mehrsafar, Gazerani, Li, Gao, Liu, \& Zhong, 2020; Zadeh \& Sanchez, 2020; Tingaz, 2020; Rubio, Sanchez-Iglesias, Bueno, \& Martin, 2021; Santi et al., 2021).

In addition, when studies conducted on burnout during the pandemic period were examined, it was found that a great majority were conducted in different countries of the world on healthcare professionals fighting on the forefront with coronavirus (Dincer \& İnangil, 2020; Fessell \& Cherniss, 2020; Janeway, 2020; Wu et al., 2020; Treluyer \& Tourneux, 2021; Ismail, Shehata, \& Mahrous, 2021; Varani et al., 2021). However, no studies were found which examined the burnout states of coaches who were seriously affected by the pandemic and who are one of the cornerstones of sport sector. As a matter of fact, in addition to the fact that there is no clear date about when we'll return to normal, restricted life conditions and compulsory physical isolation may have negatively affected the psychological health of coaches and supportive staff. It is also thought that coaches may feel professionally exhausted since they haven't been able to coach and spend time with their athletes for a long time due to the pandemic and since they have financial losses. Santi et al. (2021) reported that the recent global spread of COVID-19 pandemic affected the lives of people in many countries including athletes, coaches and supportive staff; coaches were included in the isolation just like everyone and this may have normally affected the psychological well-being of coaches since they had limited ability to be engaged in their profession and interact with athletes. In addition, the issue of burnout is important for judo coaches because when coaches begin to feel emotionally exhausted, they distance themselves from athletes and they begin to lose sense of their job; therefore, there is no doubt that burnout is considered as a factor that affects the quality of athletic experience both for coaches and also for athletes (S. Gencay \& O. Gencay, 2011).

In the light of the information above, this study was carried out to find out the burnout levels of judo coaches in isolation days due to the present coronavirus (COVID-19) pandemic and to show how they will approach their profession and athletes in the period after the pandemic by using mixed method.

\section{Method}

This part of the study will give information about the research model, research group, data collection tools used in the research and data analysis.

\subsection{Research Model}

A mixed method was used in this study to find out the burnout levels of judo coaches from different coaching levels during the COVID-19 pandemic period. Mixed method research is a model used in health, social and behavioural science areas where the researcher integrates the 
data sets by collecting both qualitative and quantitative data to understand the research problem and then draws conclusions by using the advantages of integrating these two sets together (Creswell, 2017). Parallel mixed method, one of the mixed method designs, was used in this study. The aim of parallel mixed method researches is to collect both qualitative and quantitative data at the same time, to combine these data and to use the results to understand a research problem (Firat, Yurdakul, \& Ersoy, 2014).

Phenomenology design was preferred for qualitative dimension. Phenomenology design is an inquiry strategy in which the researcher tries to define the essence of human experiences about a phenomenon explained by the participants (Creswell, 2003).

\subsection{Participants}

Convenience (random) sampling method was chosen in this study. Random sampling selection does not require a detailed study. Therefore, it is not possible to mention a systematic sampling process. The size of the sample generally depends on the preference of the researcher (Baştürk \& Taştepe, 2013). In this context, the research group of the present study consists of a total of 136 judo coaches, 90 (66.2\%) males and 46 (33.8\%) females. These coaches cannot perform their profession due to the restrictions brought by the pandemic.

\subsection{Data Collection Tools}

\subsubsection{Personal Information Form}

A personal information form prepared by the researchers was used in the study to find out the demographic characteristics of judo coaches such as gender, age and coaching level.

\subsubsection{Maslach Burnout Scale}

Maslach Burnout Inventory developed by Maslach and Jackson in 1981 was used in the study. The inventory was adapted into Turkish by Ergin (1992). The inventory has three sub-dimensions as emotional exhaustion, depersonalization and personal accomplishment.

The scale is a 5 Likert type scale and while scoring, emotional exhaustion and depersonalization sub-dimension items are scored as 1 "Never"; 2 "Rarely"; 3 "Sometimes"; 4 "Mostly" and 5 "Always", while the items are reversely scored in personal accomplishment sub-dimension. Cronbach alpha $(\alpha)$ values of the scale and its sub-dimensions are as follows: emotional exhaustion (.874), depersonalization (.718), personal accomplishment (.790) and the whole inventory $(.880)$. The inventory can be said to be reliable since these values are very close to 1 (Tavakol and Dennick, 2011).

\subsubsection{Semi-structured Interview Form}

An interview form consisting of 3 open-ended questions was used to find out the approaches of judo coaches in the pandemic and post-pandemic period towards their profession and athletes. The form, which initially consisted of 4 open-ended questions, was edited as 3 open-ended questions in line with the opinions of field experts and partially supported Maslach Burnout Inventory. The open-ended questions in the form are as follows, 
Question 1: Because I cannot perform my profession due to COVID-19 pandemic, I feel ...

Question 2: When the COVID-19 pandemic ends, while performing my profession, I will feel ...

Question 3: My approach to athletes before COVID-19 pandemic was ...; after the pandemic, it will be ...

\subsection{Data Collection and Analysis}

Data collection tools prepared by the researchers were transferred to online platform, the form was sent to judo coaches and they were asked to participate in the study on a voluntary basis. IBM SPSS 22 program was used to analyze the data obtained in the study. As a result of the normality analysis, it was found that the data did not show a normal distribution (Table 1). Non-parametric Mann Whitney U was used for paired group comparisons, while Kruskal Wallis $\mathrm{H}$ test was used for the comparison of more than two groups and significance level was taken as $\mathrm{p}<.05$. The answers given to qualitative questions were analyzed with content analysis method and they were gathered under appropriate headings by reviewing literature and presented in tables.

In the qualitative part of the study, content analysis method was used to analyze the responses of judo coaches to the open-ended questions. The order of content analysis is as follows: coding the data, finding the themes, organizing the data according to themes-codes and interpreting the results. The qualitative data set was coded according to coaching level, age range, gender and the sequence number given by the researchers.

For example: a 2nd level, 25-year-old female participant participated in the study in the 9th place. This data was coded as 2,2,F,9. The age interval was coded as 18-22 years of age (1), 23-27 years of age (2), 28-32 years of age (3), 33-37 years of age (4), $38+(5)$.

Content analysis method was preferred for the analysis of qualitative data. In the study, the answers to the 3 open-ended questions and a total of 6 sub theme were obtained. As an internal measure of reliability, the consensus among the three researchers was calculated as marking "consensus" or "disagreement", as proposed by Miles, Huberman and Saldana (1994) and $85 \%$ consensus was reached on the data obtained from the open-ended questions.

\subsection{Ethics Content}

The document confirming that this study is in compliance with ethical rules was obtained from Kilis 7 Aralık University Ethics Committee (Issue: E-76062934-044 Date: 16.03.2021). 
Table 1. Results of normality test of data

\begin{tabular}{|l|l|l|}
\hline & Skewness & Kurtosis \\
\hline Emotional Exhaustion & 1.627 & 1.992 \\
\hline Depersonalization & 1.813 & -1.370 \\
\hline Personal Accomplishment & 1.506 & 3.726 \\
\hline Total Burnout & 1.516 & .933 \\
\hline
\end{tabular}

In Table 1, it was determined that the total of the scale and its sub-dimensions do not show a normal distribution since the skewness and kurtosis values are not between -1.5 and +1.5 (Tabachnick \& Fidell, 2013). For this reason, nonparametric tests were preferred in this study.

\section{Results}

Table 2. Demographic characteristic of judo coaches

\begin{tabular}{|l|l|l|l|}
\hline \multirow{4}{*}{ Gender } & & $\mathrm{n}$ & $\%$ \\
\hline \multirow{5}{*}{ Age } & Male & 90 & 66.2 \\
\cline { 2 - 4 } & Female & 46 & 33.8 \\
\hline & $18-22$ & 13 & 9.6 \\
\cline { 2 - 5 } & $23-27$ & 41 & 30.1 \\
\cline { 2 - 5 } Coaching Level & $28-32$ & 31 & 22.8 \\
\cline { 2 - 5 } & $33-37$ & 21 & 15.4 \\
\cline { 2 - 5 } & 38 age and + & 30 & 22.1 \\
\hline & 1 st level & 33 & 24.3 \\
\cline { 2 - 5 } & 2nd level & 53 & 39.0 \\
\cline { 2 - 4 } & 3rd level & 37 & 27.2 \\
\cline { 2 - 4 } & 4th level & 13 & 9.6 \\
\hline
\end{tabular}

As Table 2 is examined, it can be seen that the total number of judo coaches is 136 . Of these, $90(66.2 \%)$ are male, while $46(33.8 \%)$ are female. $13(9.6 \%)$ of the judo coaches are between 18 and 22 years of age, $41(30.1 \%)$ are between 23 and 27 years of age, $31(22.8 \%)$ are between 28 and 32 years of age, $21(15.4 \%)$ are between 33 and 37 years of age and 30 $(22.1 \%)$ are 38 years of age and older. When the levels of coaches were examined, it was found that $33(24.3 \%)$ are first level coaches, 53 (39.0\%) are second level coaches, $37(27.2 \%)$ 
are third level coaches and $13(9.6 \%)$ are fourth level coaches.

Table 3. Score descriptive features of judo coaches to burnout scale

\begin{tabular}{|l|l|l|l|l|l|}
\hline Scale & $\mathrm{N}$ & Min. & Max. & Mean & Std. Dev. \\
\hline Emotional Exhaustion & 136 & 1.00 & 4.89 & 1.88 & .760 \\
\hline Depersonalization & 136 & 1.00 & 4.00 & 1.74 & .695 \\
\hline Personal Accomplishment & 136 & 1.25 & 4.50 & 2.16 & .480 \\
\hline Total Burnout & 136 & 1.18 & 3.86 & 1.95 & .510 \\
\hline
\end{tabular}

As Table 3, is examined, it was found that total burnout levels of judo coaches were low $(\overline{\mathrm{x}}=$ 1.95) and the most negatively affected aspect during the pandemic was personal accomplishment $(\overline{\mathrm{x}}=2.16)$ sub-dimension.

Table 4. Mann Whitney U Test results according to gender variable of judo coaches

\begin{tabular}{|c|c|c|c|c|c|c|c|}
\hline Scale Total and Sub-dimensions & Gender & $\mathrm{N}$ & Mean Rank & Total Rank & $\mathrm{Z}$ & $\mathrm{U}$ & $\mathrm{p}$ \\
\hline \multirow{2}{*}{ Emotional Exhaustion } & Male & 90 & 67.91 & 6112.00 & \multirow{2}{*}{-.244} & \multirow{2}{*}{2017.000} & \multirow{2}{*}{.807} \\
\hline & Female & 46 & 69.65 & 3204.00 & & & \\
\hline \multirow{2}{*}{ Depersonalization } & Male & 90 & 69.29 & 6236.00 & \multirow{2}{*}{-.329} & \multirow{2}{*}{1999.000} & \multirow{2}{*}{.742} \\
\hline & Female & 46 & 66.96 & 3080.00 & & & \\
\hline \multirow{2}{*}{ Personal Accomplishment } & Male & 90 & 68.14 & 6133.00 & \multirow{2}{*}{-.148} & \multirow{2}{*}{2038.000} & \multirow{2}{*}{.882} \\
\hline & Female & 46 & 69.20 & 3183.00 & & & \\
\hline \multirow{2}{*}{ Total Burnout } & Male & 90 & 68.33 & 6150.00 & \multirow{2}{*}{-.069} & \multirow{2}{*}{2055.000} & \multirow{2}{*}{.945} \\
\hline & Female & 46 & 68.83 & 3166.00 & & & \\
\hline
\end{tabular}

Note. $* \mathrm{p}<.05$.

As Table 4 is examined, it was found that as a result of the Mann Whitney U test, mean ranks of judo coaches' burnout inventory and sub-dimensions (emotional exhaustion, depersonalization and personal accomplishment) did not differ significantly in terms of the variable of gender. 
Table 5. Kruskal Wallis H Test result according to the age variable of judo coaches

\begin{tabular}{|c|c|c|c|c|c|c|}
\hline Scale Total and Sub-dimensions & Age & $\mathrm{N}$ & Mean Rank & df & $X^{2}$ & $\mathrm{p}$ \\
\hline \multirow{5}{*}{ Emotional Exhaustion } & $18-22$ & 13 & 61.69 & \multirow{5}{*}{4} & \multirow{5}{*}{7.645} & \multirow{5}{*}{.105} \\
\hline & $23-27$ & 41 & 75.65 & & & \\
\hline & $28-32$ & 31 & 52.87 & & & \\
\hline & $33-37$ & 31 & 73.71 & & & \\
\hline & +38 & 30 & 74.18 & & & \\
\hline \multirow{5}{*}{ Depersonalization } & $18-22$ & 13 & 52.85 & \multirow{5}{*}{4} & \multirow{5}{*}{4.983} & \multirow{5}{*}{.289} \\
\hline & $23-27$ & 41 & 73.29 & & & \\
\hline & $28-32$ & 31 & 73.50 & & & \\
\hline & $33-37$ & 31 & 73.57 & & & \\
\hline & +38 & 30 & 60.02 & & & \\
\hline \multirow{5}{*}{ Personal Accomplishment } & $18-22$ & 13 & 67.50 & \multirow{5}{*}{4} & \multirow{5}{*}{6.024} & \multirow{5}{*}{.197} \\
\hline & $23-27$ & 41 & 80.55 & & & \\
\hline & $28-32$ & 31 & 65.23 & & & \\
\hline & $33-37$ & 31 & 63.02 & & & \\
\hline & +38 & 30 & 59.68 & & & \\
\hline \multirow{5}{*}{ Total Burnout } & $18-22$ & 13 & 59.85 & \multirow{5}{*}{4} & \multirow{5}{*}{3.603} & \multirow{5}{*}{.462} \\
\hline & $23-27$ & 41 & 76.93 & & & \\
\hline & $28-32$ & 31 & 61.29 & & & \\
\hline & $33-37$ & 31 & 69.86 & & & \\
\hline & +38 & 30 & 67.23 & & & \\
\hline
\end{tabular}

Note. $* \mathrm{p}<.05$.

As Table 5 is examined, it was found that as a result of the Kruskal Wallis $\mathrm{H}$ test results, mean ranks of judo coaches' burnout inventory and sub-dimensions (emotional exhaustion, depersonalization and personal accomplishment) did not differ significantly in terms of the variable of age. 
Table 6. Kruskal Wallis H Test results according to the grade variable of judo coaches

\begin{tabular}{|c|c|c|c|c|c|c|}
\hline Scale Total and Sub-dimensions & Level & $\mathrm{N}$ & Mean Rank & df & $X^{2}$ & $\mathrm{p}$ \\
\hline \multirow{4}{*}{ Emotional Exhaustion } & 1. & 33 & 63.02 & \multirow{4}{*}{3} & \multirow{4}{*}{6.781} & \multirow{4}{*}{.079} \\
\hline & 2. & 53 & 68.12 & & & \\
\hline & 3. & 37 & 64.72 & & & \\
\hline & 4. & 13 & 94.73 & & & \\
\hline \multirow{4}{*}{ Depersonalization } & 1. & 33 & 64.15 & \multirow{4}{*}{3} & \multirow{4}{*}{.941} & \multirow{4}{*}{.816} \\
\hline & 2. & 53 & 72.25 & & & \\
\hline & 3. & 37 & 67.26 & & & \\
\hline & 4. & 13 & 67.77 & & & \\
\hline \multirow{4}{*}{ Personal Accomplishment } & 1. & 33 & 73.27 & \multirow{4}{*}{3} & \multirow{4}{*}{1.258} & \multirow{4}{*}{.739} \\
\hline & 2. & 53 & 69.37 & & & \\
\hline & 3. & 37 & 62.95 & & & \\
\hline & 4. & 13 & 68.65 & & & \\
\hline \multirow{4}{*}{ Total Burnout } & 1. & 33 & 66.03 & \multirow{4}{*}{3} & \multirow{4}{*}{4.941} & \multirow{4}{*}{.176} \\
\hline & 2. & 53 & 70.25 & & & \\
\hline & 3. & 37 & 61.12 & & & \\
\hline & 4. & 13 & 88.65 & & & \\
\hline
\end{tabular}

Note. ${ }^{*} \mathrm{p}<.05$.

As Table 6 is examined, it was found that as a result of the Kruskal Wallis $H$ test results, mean ranks of judo coaches' burnout inventory and sub-dimensions (emotional exhaustion, depersonalization and personal accomplishment) did not differ significantly in terms of the variable of coaching level. 


\section{Macrothink}

Table 7. The responses of judo coaches to the first qualitative question and the headings under which responses are grouped

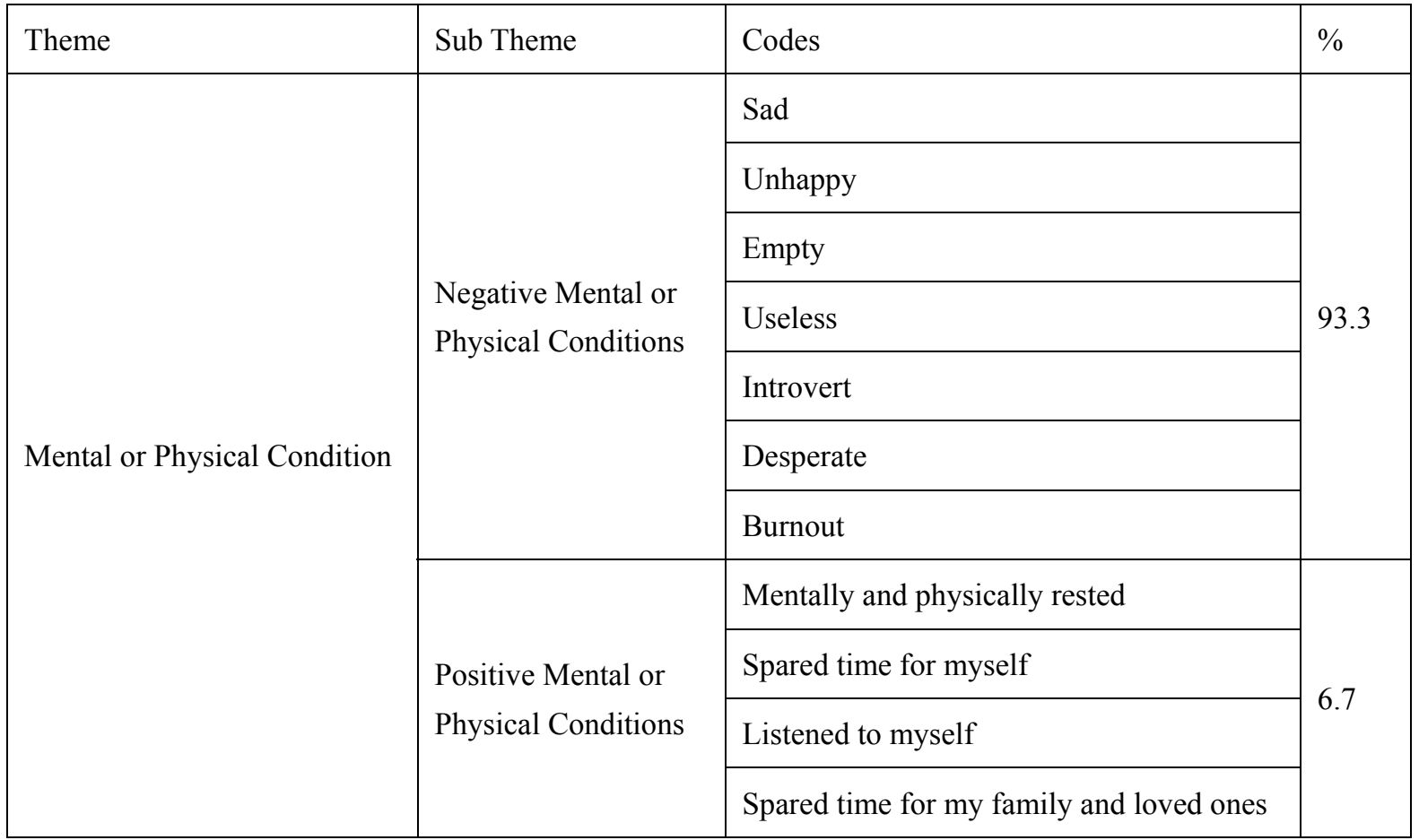

As Table 7 is examined, the responses of judo coaches who could not perform their professions given to the question "Because I cannot perform my profession due to COVID-19 pandemic, I feel ..." were analyzed with content analysis method. When the responses were examined, it was found that a coach coded as 2,1,M,49 said that he felt "unhappy", while a coach coded as 4,2,F,52 said that she felt "sad" and similar responses could be expressed as "Negative situations caused by the quarantine practices due to the pandemic". A coach coded as 1,1,M,31 responded "I have spared time for myself". Another coach coded as 2,1,M,12 responded "I have rested". Similar responses were expressed as "Positive situations caused by the quarantine practices due to the pandemic". 


\section{Macrothink}

Journal of Educational Issues

ISSN 2377-2263

2021, Vol. 7, No. 1

Table 8 . The responses of judo coaches to the second qualitative question and the headings under which responses are grouped

\begin{tabular}{|c|c|c|c|}
\hline Theme & Sub Theme & Codes & $\%$ \\
\hline \multirow{10}{*}{ Mental or Physical Condition } & \multirow{6}{*}{$\begin{array}{l}\text { Positive Mental or } \\
\text { Physical Conditions }\end{array}$} & Energetic & \multirow{6}{*}{95.4} \\
\hline & & $\begin{array}{l}\text { Willing as if I had just } \\
\text { started the profession }\end{array}$ & \\
\hline & & Happy & \\
\hline & & Excited & \\
\hline & & Longing & \\
\hline & & More motivated & \\
\hline & \multirow{4}{*}{$\begin{array}{l}\text { Negative Mental or } \\
\text { Physical Conditions }\end{array}$} & Estranged from my profession & \multirow{4}{*}{4.6} \\
\hline & & My efforts wasted & \\
\hline & & Exhausted & \\
\hline & & Physically tired & \\
\hline
\end{tabular}

As Table 8 is examined, to the question "When the COVID-19 pandemic ends, while performing my profession, I will feel ...", 1,3,F,62 coded coach responded as "energetic and devoted to the profession", another coach coded 3,4,M,75 responded as "more motivated. Such responses were collected by the researchers under the heading of "Positive situations caused by being away from the profession due to pandemic". A coach coded as 2,1,M,12 responded to this question as "estranged from my profession", while another coach coded as 3,3,F,88 responded as "my efforts wasted". Similar responses were collected by the researchers under the heading of "Negative situations caused by being away from the profession due to pandemic". 
Table 9. The responses of judo coaches to the third qualitative question and the headings under which responses are grouped

\begin{tabular}{|l|l|l|l|}
\hline Theme & Sub Themes & Codes & $\%$ \\
\hline \multirow{4}{*}{ Approach } & \multirow{4}{*}{ Stabil Approach } & Moderate & \multirow{2}{*}{48.2} \\
\cline { 3 - 3 } & & Positive & \\
\cline { 3 - 4 } & \multirow{3}{*}{ Changing Approach } & Attentive & \multirow{2}{*}{$\begin{array}{l}\text { Performance oriented but it will be more humane } \\
\text { because we've been through a serious process. }\end{array}$} \\
\cline { 3 - 4 } & & I insisted they be more willing. I'll be more thoughtful now. & \\
\hline
\end{tabular}

As Table 9 is examined, to the question "My approach to athletes before COVID-19 pandemic was ...; after the pandemic, it will be ...", the coach coded 1,2,F,84 responded as "careful and it will be the same", another coach coded as 3,4,M,103 responded as "moderate and it will be the same". Such responses were collected by the researchers under the heading of "Sentences stating that there will be no change in their approach". The coach coded as 3,5,M,123 responded as "performance oriented but it will be more humane because we've been through a serious process" and another coach coded as 4,5,M,44 responded as "insistent on their being more eager. I will be more thoughtful". Such responses were collected by the researchers under the heading of "Sentences stating that there will be a change in their approach".

\section{Discussion}

Life has come to a standstill due to COVID-19 pandemic and most sectors such as education, sport, tourism and trade, especially health, have been negatively affected. For about a year, coaches have been away from their athletes. As a result of this distance, their burnout perceptions and how their approaches to their profession and their athletes will be after the pandemic period have been a matter of curiosity. The present study has found both the burnout levels of coaches who cannot perform their profession and their post-pandemic approaches to their profession and athletes and has also contributed to the expansion of existing knowledge.

In order to be able to cope with negative situations or stress both during competitions and also outside competitions, to be able to maintain continuity in concentration and not to experience motivation loss, coaches also have to be mentally tough as well as athletes. According to Young (2014), although coaches who are mentally tough are faced with difficulties, loss, stress, problems, changes or negative life events, they develop an effective coping strategy or adapt to the existing situation. In the light of this information, it is thought that the reason why judo coaches have low burnout levels (Table 3) may be the fact that they 
have developed an effective coping strategy due to having high mental toughness or they fight negativity by adapting to the existing situation. Although the majority of judo coaches who have been away from sport and athletes (93.3\%) have negative emotions in the pandemic (Table 7), their burnout scores show that they cope with this negative process (Table 3). In addition, it is thought that the results are also affected by the fact that there are also coaches who have turned the pandemic into an opportunity by resting and allocating more time to their loved ones (Table 7). It can also be said that another reason why judo coaches had low burnout levels may be the fact that since a great majority $(95.4 \%)$ had positive emotions about their approaches to their profession in the post-pandemic process such as "energetic, longing, excited as the first day" (Table 8), this may have contributed to their mental toughness and prevented them from having burnout. Finally, it is also thought that the reason why coaches had low burnout levels may be the fact that more than half of the coaches $(51.8 \%)$ had the opportunity to question their behaviors before the pandemic and decided to change these gave them the chance to develop themselves personally instead of having negative emotions. According to the results of a study by Santi et al. (2021) in the pandemic period, it was found that although coaches had high perceived stress level, they used emotion regulation strategies intensely.

It was found that the variables of gender, age and coaching level did not cause a significant difference on burnout perception. It is thought that since the restrictions in the pandemic period are not stretched according to demographic characteristics such as gender, branch, age, coaching level and no one is given privileges, burnout perceptions of judo coaches did not differ significantly in terms of the aforementioned variables (gender, age, coaching level). When studies conducted during the pandemic period (2019-2021) which examined the burnout states of different branch coaches are examined, there are studies which did not find a significant difference between burnout perceptions and the variables of gender (Doğan \& Akandere, 2019; Aka, Sajedi, \& Karataş, 2020; Kayğusuz \& Karagün, 2021), coaching level (Aka, Sajedi, \& Karataş, 2020) and age (Aka, Sajedi, \& Karataş, 2020) and their results are in parallel with the results of the present study. There are also studies which have found that burnout levels of coaches differ significantly in terms of their age (Pehlivan, 2020) and gender (Akbulut, 2018). These results are different from the results of the present study. The reason for this may be that the studies were carried out on different branches (wrestling and boxing) and the data were collected at different times.

As a conclusion, burnout levels of judo coaches during the pandemic period were found to be low. No significant differences were found in the perceived burnout states of coaches in terms of the variables of gender, coaching level and age. When the total burnout scores were examined, it was found that female coaches, those who were between the ages of 23 and 27 and those who were 4th level coaches felt higher burnout than the others.

\section{Recommendations}

It can be seen that there are few studies carried out on coaches, who are within the sport sector, a sector considered as the greatest sectors of the world and affected seriously by the current pandemic. Studies can be carried out which focus on how coaches or athletes cope 
with this negative process, their concerns and mental toughness and recommendations can be made accordingly. Studies can be conducted which provide suggestions that will enable stakeholders in the sports community to spend this process efficiently.

\section{References}

Aka, S. T., Sajedi, H., \& Karatas, B. (2020). Education of burnout levels of coaches working with physically disabled swimmers according to various variables. African Educational Research Journal, 8(1), 129-133. https://doi.org/10.30918/AERJ.81.20.021

Akbulut, A. (2018). Taekwondo and boxing trainers comparison of burnout levels (Unpublished master's dissertation, Akdeniz University, Turkey).

Aygün, M., \& Ünal, M. (2020). COVID-19 pandemisinin buz hokeyi sporuna etkisi. Anadolu Kliniği Tıp Bilimleri Dergisi, 25(Special Issue on COVID 19), 195-203. https://doi.org/ 10.21673/anadoluklin.738039

Baggish, A., Drezner, J. A., Kim, J., Martinez, M., \& Prutkin, J. M. (2020). Resurgence of sport in the wake of COVID-19: Cardiac considerations in competitive athletes. British Journal of Sports Medicine, 54(19), 1130-1131. https://doi.org/10.1136/bjsports-2020102516

Baştürk, S., \& Taştepe, M. (2013). Evren ve örneklem. Bilimsel Araştırma Yöntemleri (pp. 129-159). Ankara: Vize Yayıncilık.

Creswell, J. W. (2003). Research design: Qualitative, quantitative, and mixed methods approaches (2nd ed.). Thousand Oaks, CA: Sage.

Creswell, J. W. (2017). In M. Sözbilir (Ed.), A concise introduction to mixed methods research. Ankara, Turkey: Pegem.

Dalton, L., Rapa, E., \& Stein, A. (2020). Protecting the psychological health of children through effective communication about COVID-19. The Lancet Child \& Adolescent Health, 4(5), 346-347. https://doi.org/10.1016/S2352-4642(20)30097-3

Dhillon, M. S. (2020). Olympics in the time of a pandemic. Indian J. Orthop., 54(3), 231-232. https://doi.org/10.1007/s43465-020-00103-9

Dincer, B., \& Inangil, D. (2020). The effect of Emotional Freedom Techniques on nurses' stress, anxiety, and burnout levels during the COVID-19 pandemic: A randomized controlled trial. Explore, 17(2), 109-114. https://doi.org/10.1016/j.explore.2020.11.012

Doğan, M., \& Akandere, M. (2019). Taekwondo antrenörlerinin iş doyumu ve tükenmişlik düzeylerinin incelenmesi. SPORMETRE Beden Eğitimi ve Spor Bilimleri Dergisi, 17(2), 154-162. https://doi.org/10.33689/spormetre.452334

Ergin, C. (1992). Doktor ve hemşirelerde tükenmislik ve Maslach tükenmislik ölceginin uyarlanmast. VII Ulusal Psikoloji Kongresi, September 22, 1992, Ankara, Turkey.

Fessell, D., \& Cherniss, C. (2020). Coronavirus disease 2019 (COVID-19) and beyond: 
micropractices for burnout prevention and emotional wellness. Journal of the American College of Radiology, 17(6), 746-748. https://doi.org/10.1016/j.jacr.2020.03.013

Fırat, M., Yurdakul, I. K., \& Ersoy, A. (2014). Bir eğitim teknolojisi araştırmasına dayalı olarak karma yöntem araştırması deneyimi. Eğitimde Nitel Araştırmalar Dergisi, 2(1), 64-85. https://doi.org/10.14689/issn.2148-2624.1.2s3m

Gencay, S., \& Gencay, O. (2011). Burnout among judo coaches in Turkey. Journal of Occupational Health, 53, 365-370. https://doi.org/10.1539/joh.10-0064-FS

Goodger, K., Lavallee, D., Gorley, T., \& Harwood, C. (2007). Burnout in sport: A systematic review. The Sport Psychologist, 21, 127-151. https://doi.org/10.1123/tsp.21.2.127

Håkansson, A., Jönsson, C., \& Kenttä, G. (2020). Psychological Distress and Problem Gambling in Elite Athletes during COVID-19 Restrictions-A Web Survey in Top Leagues of Three Sports during the Pandemic. International Journal of Environmental Research and Public Health, 17(18), 6693. https://doi.org/10.3390/ijerph17186693

Hull, J. H., Loosemore, M., \& Schwellnus, M. (2020). Respiratory health in athletes: facing the COVID-19 challenge. The Lancet Respiratory Medicine, 8(6), 557-558. https://doi.org/ $10.1016 / \mathrm{S} 2213-2600(20) 30175-2$

Ismail, T. I., Shehata, S. F., \& Mahrous, R. S. S. (2021). Occupational stress and burnout among frontline Egyptian anesthesiologists during COVID-19 outbreak in Egypt. Egyptian Journal of Anaesthesia, 37(1), 91-99. https://doi.org/10.1080/11101849.2021.1891704

Isoard-Gautheur, S., Trouilloud, D., Gustafsson, H., \& Guillet-Descas, E. (2016). Associations between the perceived quality of the coach-athlete relationship and athlete burnout: An examination of the mediating role of achievement goals. Psychol. Sport Exerc., 22, 210-217. https://doi.org/10.1016/j.psychsport.2015.08.003

Janeway, D. (2020). The role of psychiatry in treating burnout among nurses during the COVID-19 pandemic. Journal of Radiology Nursing, 39(3), 176-178. https://doi.org/10.1016/ j.jradnu.2020.06.004

Kayğusuz, Ş., \& Karagün, E. (2021) İstanbul Avrupa Yakası fitness antrenörlerinin tükenmişlik, stresle başa çıkma ve yardım arama tutumları. OPUS Uluslararası Toplum Araştırmaları Dergisi, 17(35), 127-147. https://doi.org/10.26466/opus.784499

Li, J., Gao, H., Liu, P., \& Zhong, C. (2020). Does distance produce beauty? the influence of COVID-19 lockdown on the coach-athlete relationship in a Chinese Football School. Front. Psychol., 11, 560638. https://doi.org/10.3389/fpsyg.2020.560638

Maslach C, Jackson SE. (1981). The measurement of experienced burnout. Journal of Occupational Behavior, 2, 99-113. https://doi.org/10.1002/job.4030020205

Mehrsafar, A. H., Gazerani, P., Zadeh, A. M., \& Sánchez, J. C. J. (2020). Addressing potential impact of COVID-19 pandemic on physical and mental health of elite athletes. Brain, Behavior, and Immunity, 87, 147-148 https://doi.org/10.1016/j.bbi.2020.05.011 
Miles, M. B., Huberman, M. A., \& Saldana, J. (1994). Qualitative data analysis: An Expanded Sourcebook. Thousand Oaks, CA: Sage.

Monfared, S. S., Lebeau, J. C., Mason, J., Cho, S. K., Basevitch, I., Perry, I., ... Tenenbaum, G. (2021). A bio-physio-psychological investigation of athletes' burnout. Research Quarterly for Exercise and Sport, 92(1), 189-198. https://doi.org/10.1080/02701367.2020.1715911

Öktem, T., Şipal, O., Kul, M., \& Dilek, A. N. (2020). Olimpiyat oyunlarına katılmaya aday boksörlerin COVID-19 kayg1 düzeylerinin incelenmesi. Journal of Social and Humanities Sciences Research, 7(62), 3620-3627. https://doi.org/10.26450/jshsr.2210

Pehlivan, M. H. (2020), Relation between the job satisfaction and burnout levels of wrestling coaches (Unpublished master's dissertation, Ankara Yıldırım Beyazit University, Turkey).

Rajpal, S., Tong, M. S., Borchers, J., Zareba, K. M., Obarski, T. P., Simonetti, O. P., \& Daniels, C. J. (2021). Cardiovascular magnetic resonance findings in competitive athletes recovering from COVID-19 infection. JAMA Cardiology, 6(1), 116-118. https://doi.org/ 10.1001/jamacardio.2020.4916

Rubio, V. J., Sánchez-Iglesias, I., Bueno, M., \& Martin, G. (2021). Athletes’ psychological adaptation to confinement due to COVID-19: A longitudinal study. Front. Psychol., 11, 613495. https://doi.org/10.3389/fpsyg.2020.613495

Santi, G., Quartiroli, A., Costa, S., Di Fronso, S., Montesano, C., Di Gruttola, F., ... Bertollo, M. (2021). The impact of the COVID-19 lockdown on coaches' perception of stress and emotion regulation strategies. Front. Psychol., 11, 601743. https://doi.org/10.3389/fpsyg.2020. 601743

Schinke, R., Papaioannou, A., Henriksen, K., Si, G., Zhang, L., \& Haberl, P. (2020). Sport psychology services to high performance athletes during COVID-19. International Journal of Sport and Exercise Psychology, 18(3), 269-272. https://doi.org/10.1080/1612197X.2020. 1754616

Tabachnick, B. G., \& Fidell, L. S. (2013). Using Multivariate Statistics (6th ed.). Pearson, Boston.

Taku, K., \& Arai, H. (2020). Impact of COVID-19 on athletes and coaches, and their values in Japan: Repercussions of postponing the Tokyo 2020 olympic and paralympic games. Journal of Loss and Trauma, 25(8), 623-630. https://doi.org/10.1080/15325024.2020. 1777762

Tavakol, M., \& Dennick, R. (2011). Making sense of Cronbach's alpha. International Journal of Medical Education, 2, 53-55. https://doi.org/10.5116/ijme.4dfb.8dfd

Tingaz, E. O. (2021). The psychological impact of COVID-19 pandemic on elite athletes, management strategies and post-pandemic performance expectations: A semi structured interview study. International Journal of Educational Research and Innovation, 15, 73-81. https://doi.org/10.46661/ijeri.4863 
Treluyer, L., \& Tourneux, P. (2021). Burnout among paediatric residents during the COVID-19 outbreak in France. European Journal of Pediatrics, 180(2), 627-633. https://doi.org/10.1007/s00431-020-03907-x

Varani, S., Ostan, R., Franchini, L., Ercolani, G., Pannuti, R., Biasco, G., \& Bruera, E. (2021). Caring advanced cancer patients at home during COVID-19 outbreak: Burnout and psychological morbidity among palliative care professionals in Italy. Journal of Pain and Symptom Management, 61(2), e4-e12. https://doi.org/10.1016/j.jpainsymman.2020.11.026

WHO (World Health Organization). (2020). Coronavirus Disease 2019 (COVID-19): Situation Report-52. WHO, Geneva. Retrieved June 19, 2020, from https://www.who.int/ docs/default-source/coronaviruse/situation-reports/20200312-sitrep-52-COVID-19.pdf?sfvrsn $=\mathrm{e} 2 \mathrm{bfc} 9 \mathrm{c} 0 \_4$

Wilson, M. G., Hull, J. H., Rogers, J., Pollock, N., Dodd, M., Haines, J., ... Sharma, S. (2020). Cardiorespiratory considerations for return-to-play in elite athletes after COVID-19 infection: a practical guide for sport and exercise medicine physicians. British Journal of Sports Medicine, 54(19), 1157-1161. https://doi.org/10.1136/bjsports-2020-102710

Wong, A. Y. Y., Ling, S. K. K., Louie, L. H. T., Law, G. Y. K., So, R. C. H., Lee, D. C. W., ... \& Yung, P. S. H. (2020). Impact of the COVID-19 pandemic on sports and exercise. Asia-Pacific Journal of Sports Medicine, Arthroscopy, Rehabilitation and Technology, 22, 39-44. https://doi.org/10.1016/j.asmart.2020.07.006

Wu, Y., Wang, J., Luo, C., Hu, S., Lin, X., Anderson, A. E., ... Qian, Y. (2020). A comparison of burnout frequency among oncology physicians and nurses working on the frontline and usual wards during the COVID-19 Epidemic in Wuhan, China. Journal of Pain and Symptom Management, 60(1), e60-e65. https://doi.org/10.1016/j.jpainsymman.2020.04.008

Yeo, T. J. (2020). Sport and exercise during and beyond the COVID-19 pandemic. European Journal of Preventive Cardiology, 27(12), 1239-1241. https://doi.org/10.1177/20474873209 33260

Young, J. A. (2014). Coach resilience: What it means, why it matters, and how to build it. Coaching and Sport Science Review, 22, 10-12

Yousfi, N., Bragazzi, N. L., Briki, W., Zmijewski, P., \& Chamari, K. (2020). The COVID-19 pandemic: how to maintain a healthy immune system during the lockdown-A multidisciplinary approach with special focus on athletes. Biology of Sport, 37(3), 211-216. https://doi.org/10.5114/biolsport.2020.95125

Yu, M., Li, Z., Yu, Z., He, J., \& Zhou, J. (2020). Communication related health crisis on social media: A case of COVID-19 outbreak. Current Issues in Tourism, 1-7. https://doi.org/ $10.1080 / 13683500.2020 .1752632$ 


\section{Copyright Disclaimer}

Copyright for this article is retained by the author(s), with first publication rights granted to the journal.

This is an open-access article distributed under the terms and conditions of the Creative Commons Attribution license (http://creativecommons.org/licenses/by/3.0/). 